\title{
The plausible mechanisms of action of Carica papaya on Dengue infection: A comprehensive review
}

\author{
Zhui Ken Bok ${ }^{1}$, Manisha Balakrishnan ${ }^{1}+$, Yong Xin Jong ${ }^{1}+$, Yew Rong Kong ${ }^{1}+$, Kooi Yeong Khaw ${ }^{1,2}$, \\ Yong Sze Ong ${ }^{1,3 *}$ \\ ${ }^{1}$ Biofunctional Molecule Exploratory (BMEX) Research Group, School of Pharmacy, Monash University Malaysia \\ ${ }^{2}$ Tropical Medicine \& Biology Platform, Monash University Malaysia, Bandar Sunway 47500, Malaysia \\ ${ }^{3}$ Health and Well-Being Cluster, Global Asia in the 21st Century (GA21) Platform, Monash University Malaysia, Bandar \\ Sunway 47500, Malaysia
}

\begin{abstract}
Dengue is a serious health endemic with a prediction that 2.5 billion are at risk of acquiring dengue infection and 50 million are infected yearly. Over the years, tremendous effort has been done to develop potential treatment for dengue infection. However, to no avail, most of the treatment modalities have failed in clinical evaluation and trials. With the lack of treatment for dengue infection, home remedies have been widely used as a belief to relieve the symptoms, one of them is the use of papaya leaf juice. This review provides a recent evidences and research that have been attempted to unravel the mechanism of actions of papaya leaf extract to treat dengue infection. Up to date, there are three main mechanisms that have been proposed, which are the anti-thrombocytopenic, immunomodulatory and anti-viral effect of papaya leaf juice extract.
\end{abstract}

Keywords: Carica papaya; dengue; Aedes ayegypti; platelet; mechanism

Received: $21^{\text {st }}$ May 2020

Accepted: $21^{\text {st }}$ June 2020

Published Online: $30^{\text {th }}$ June 2020

+Authors contributed equally to this work

*Correspondence: Yong Sze Ong, Health and Well-Being Cluster, Global Asia in the 21st Century (GA21) Platform, Monash University Malaysia, Bandar Sunway 47500, Malaysia, Biofunctional Molecule Exploratory (BMEX) Research Group, School of Pharmacy, Monash University Malaysia Bandar Sunway, Selangor, Malaysia; ong.yongsze@monash.edu.

Citation: Bok ZK, Balakrishnan M, Jong YX, et al. The plausible mechanisms of action of Carica papaya on Dengue infection: A comprehensive review. Prog Drug Discov Biomed Sci 2020; 3(1): a0000097. https://doi.org/10.3687/pddbs.a0000097.

\section{Introduction}

Dengue fever is a most prevalent infection caused by the Flavivirus (family: Flaviviridae) that transmitted by the female vector mosquito Aedes ayegypti ${ }^{[1]}$. One of the main regions that are infected with the dengue are the America, Africa and Asia countries such as Malaysia, Philippines, Singapore, Sri Lanka and Thailand, with an estimated mortality of 9 per million populations reported in $2013^{[2]}$ (Figure 1). As a global endemic, it is predicted that 2.5 billion are at risk of acquiring dengue infection and 50 million are infected yearly ${ }^{[3]}$. Dengue infections can be caused by 4 serotypes of virus which are DEN-1, DEN-2, DEN-3 and DEN-4 ${ }^{[4]}$. DENV-1 was first reported in French Polynesia and Japan, and constantly increased over time in Asian regions. Meanwhile DENV-2 was first reported in Indonesia and Papua New Guinea and spread thru Asian regions such as Malaysia,
Thailand, the Philippines and Singapore since then. Both DENV-3 and DENV-4 were reported much later in 1953 in the Philippines and Thailand $d^{[5]}$.

Studies have been done to figure out the relationship between the dengue serotypes and their respective clinical manifestations. Infection with DEN-1 and DEN-3 has mild clinical manifestations, whereas infection cases with DENV-2 showed severe manifestations amongst all ${ }^{[5]}$. The infection varies from asymptomatic illness to severe ones such as haemorrhagic fever and dengue shock syndrome. The clinical manifestations of dengue infections are thrombocytopenia, leukopenia, and transient neutrophil deficiency with coagulation abnormalities ${ }^{[6]}$. It is suggested that those manifestations are due to the abilities of dengue virus in inhibition of the megakaryocytes differentiation or activation of platelets ${ }^{[7]}$. 


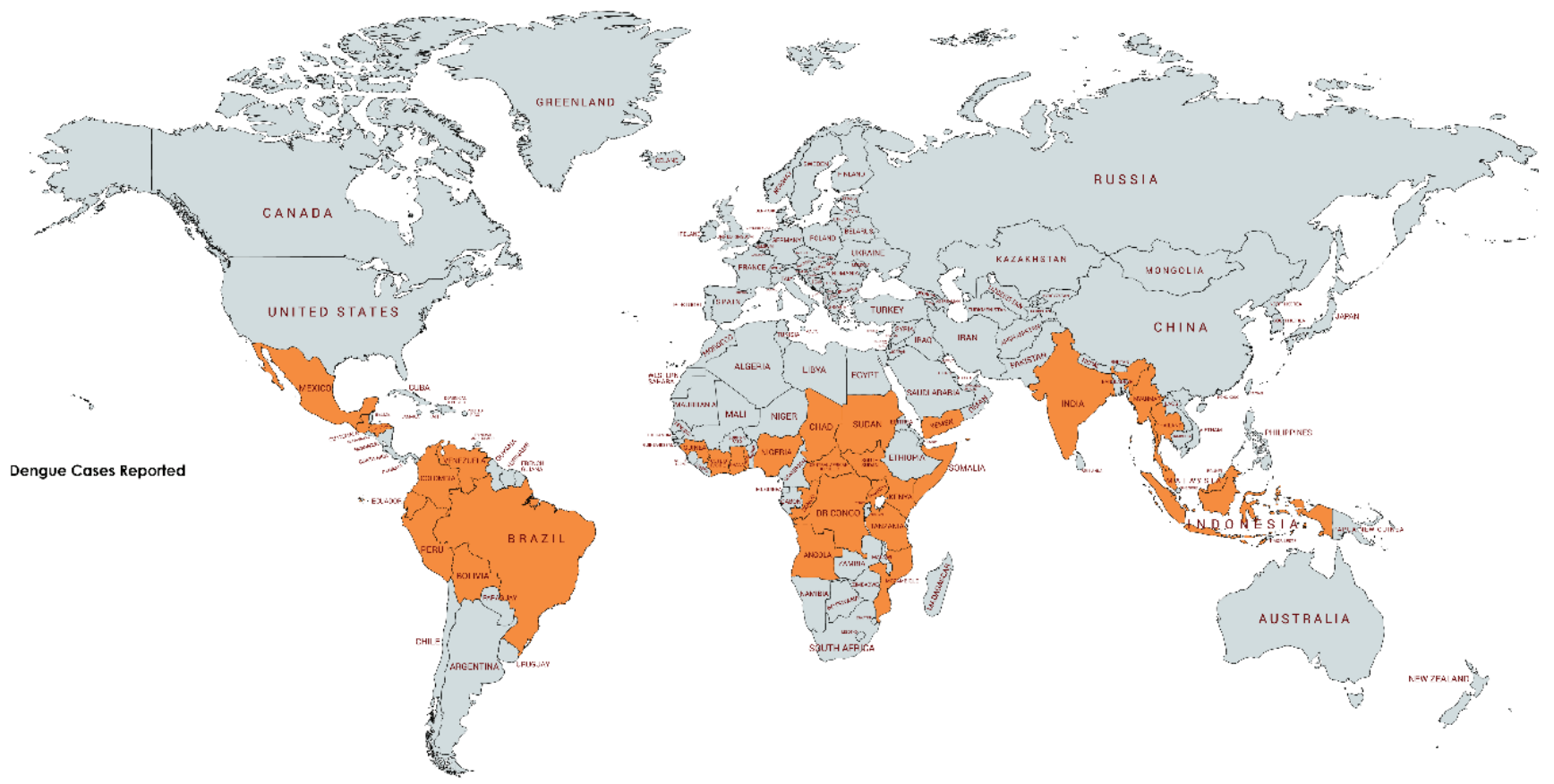

Figure 1. Geographical distribution of dengue infection worldwide $e^{[2]}$.

\section{Treatment for Dengue Infection}

As an endemic, dengue infection has caused a substantial impact on the health, social and economy globally. The estimates of economic burden of dengue are roughly 40,000 disability-adjusted life years (DALYS) annually, which inflicted a loss of US\$94.87 million per year as in $2016^{[8]}$. This figure has pursued the urgency to seek for prevention and treatment of dengue. Over the years, tremendous effort has been done to develop potential treatment modalities such as corticosteroids, immunoglobulin, host immune modulator and anti-viral agents ${ }^{[9-11]}$. However, to no avail, the mentioned modalities have failed in clinical evaluation and trials ${ }^{[11]}$. To date, the main clinical managements of dengue infection are the supportive measures such as anti-pyretic, hydration, blood transfusion and pain killers ${ }^{[12]}$. Similar to other viral infection, the dengue infection induces a life-long immunity to specific serotypes. Nevertheless, the conditions of dengue infection will be life-threatening for second infection from another serotype ${ }^{[13]}$. Currently, the only preventive measure for this infection is by preventing the bite from the mosquitoes with virus vector and by using the insecticides and larvicides which is potentially hazardous to environment and human beings.

With the lack of treatment for dengue infection, home remedies have been widely used as a belief to relieve the symptoms. In South East Asia, most of the dengue patients rely on numerous home remedies for managing dengue infection such as isotonic drinks, crab soups and papaya leaves ${ }^{[14]}$. Papaya leaf juice has been widely used by traditional healers in Asian regions such as North Eastern of India, Goa, Uttar Pradesh and Odisha in dengue patients ${ }^{[15]}$; for instance, In Thailand, papaya leaf juice is so popular during monsoon season that a delivery guy will bottle and deliver the juices all over the towns ${ }^{[16]}$. Following the popular use of papaya leaf for the treatment of dengue, research have been done to evaluate the potential of papaya leaves and its underlying mechanisms of action.

\section{Carica papaya}

Carica papaya Linn., which is commonly known as papaya or pawpaw, is the palm like tree that is the only species within the Caricaceae genus. The tree produces segmented yellow flowers and large black seeded yellow to orange fruits ${ }^{[17]}$. As a popular home-growing crops in tropical regions, the papaya has been used for centuries as a ethnomedicine to treat many diseases includes dengue fever ${ }^{[18]}$. The leaves were found to be rich in phenolic compounds such as alkaloids, quercetin and kaempferol. On top of that, the leaf extract contains antioxidant compounds such as $\alpha$-tocopherol, ascorbic acid and flavonoids ${ }^{[19-21]}$. Some case studies reported that the papaya leaves aid for better recovery of dengue in terms of clinical symptoms and platelet counts. With that, more research have been performed in recent years to elucidate the plausible mechanisms of action of papaya on dengue. From the literature review, it is suggested that the beneficial effect of papaya leaf could be exerted thru three mechanisms of action, which are the recovery of platelet counts, inhibition of pro-inflammatory cytokines and larvacidal effect (Table 1). As presented in Figure 2, this review has also compiled the timeline of the effect of papaya leaf extract, demonstrating the suitable or suggestive period of admiration of papaya leaf extract for dengue treatment. 
Table 1. The plausible mechanisms of action of papaya on dengue treatment.

\begin{tabular}{|c|c|c|c|}
\hline Authors & Study & Study Characteristics & Mechanisms \\
\hline \multicolumn{4}{|c|}{ Anti-thrombocytopenic Effect } \\
\hline $\begin{array}{l}\text { Sathiasivam et al. } \\
\text { (2009) }\end{array}$ & $\begin{array}{l}\text { In vivo (Swiss } \\
\text { albino mice) }\end{array}$ & $\begin{array}{l}\text { Oral administration of } 15 \mathrm{mg} / \mathrm{kg} \text { of powdered } \\
\text { papaya leaves in palm oil }\end{array}$ & increase in the platelet count observed within 72 hours \\
\hline $\begin{array}{l}\text { Anjum et al. } \\
(2017)\end{array}$ & In vivo (Wistar rat) & $\begin{array}{l}\text { Oral administration of } 150 \mathrm{mg} / \mathrm{kg} \text { of aqueous } \\
\text { extract of papaya leaf }\end{array}$ & $\begin{array}{l}\text { significant increase in the thrombocyte counts temporarily up to } 12 \\
\text { hours }\end{array}$ \\
\hline $\begin{array}{l}\text { Siddique et al. } \\
\text { (2014) }\end{array}$ & Human & $\begin{array}{l}\text { Oral administration of } 150 \mathrm{~mL} \text { of papaya leaf } \\
\text { juice for } 5 \text { days }\end{array}$ & $\begin{array}{l}\text { significant increase in the thrombocyte counts } \\
\text { exhibit anti-hemolytic effect }\end{array}$ \\
\hline $\begin{array}{l}\text { Sathyapalan et al. } \\
(2020)\end{array}$ & Human & $\begin{array}{l}\text { Oral administration of } 1100 \mathrm{mg} \text { of papaya leaf } \\
\text { extract in tablet three times a day for } 5 \text { days }\end{array}$ & $\begin{array}{l}\text { increase in the platelet count in the } 1 \text { st } 4 \text { days and maintained on } \\
\text { day } 5\end{array}$ \\
\hline $\begin{array}{l}\text { Subenthiran et al. } \\
\text { (2013) }\end{array}$ & Human & $\begin{array}{l}\text { Oral administration of } 50 \mathrm{mg} \text { of papaya leaf } \\
\text { juice extract once a day for } 3 \text { days }\end{array}$ & $\begin{array}{l}\text { Significant increase in the platelet counts at } 40 \text { and } 48 \text { hours } \\
15 \text {-fold increase in the gene expression of ALOX } 12\end{array}$ \\
\hline \multicolumn{4}{|c|}{ Immunomodulatory Effect } \\
\hline $\begin{array}{l}\text { Sathyapalan et al. } \\
(2020)\end{array}$ & Human & $\begin{array}{l}\text { Oral administration of } 1100 \mathrm{mg} \text { of papaya leaf } \\
\text { extract in tablet three times a day for } 5 \text { days }\end{array}$ & $\begin{array}{l}\text { initiation and activation of the coagulation and inflammation } \\
\text { pathways lead to the release of pro-inflammatory cytokines such as } \\
\text { TNG-alpha, IFN-gamma and IL-6 }\end{array}$ \\
\hline Aziz et al. (2015) & $\begin{array}{l}\text { In vitro (Mesen- } \\
\text { chymal stem cells } \\
\text { and haematopoietic } \\
\text { cells) }\end{array}$ & $\begin{array}{l}\text { Treatment of unripe papaya leaf juice extract } \\
(10 \% \mathrm{v} / \mathrm{v}) \text { for } 72 \text { hours }\end{array}$ & $\begin{array}{l}\text { Enhancement of IL- } 6 \text { secretion and lead to the proliferation, matura- } \\
\text { tion and differentiation of multipotential heamatopoietic progenitors } \\
\text { production of thrombopoietin in the liver triggered by IL-6 }\end{array}$ \\
\hline $\begin{array}{l}\text { Razak et al. } \\
(2019)\end{array}$ & $\begin{array}{l}\text { In vivo (AG129 } \\
\text { mice with non- } \\
\text { mouse adapted } \\
\text { dengue virus) }\end{array}$ & $\begin{array}{l}\text { Oral administration of } 1000 \mathrm{mg} / \mathrm{kg} \text { freeze-dried } \\
\text { papaya leaf juice for three days }\end{array}$ & $\begin{array}{l}\text { Upregulation of the gene expression of CCL-2,/MCP-1 } \\
\text { downregulation the gene expression of ITGB3, ICAM1 and FN1 }\end{array}$ \\
\hline \multicolumn{4}{|l|}{ Anti-viral Effect } \\
\hline $\begin{array}{l}\text { Chinnappan et al. } \\
\text { (2016) }\end{array}$ & $\begin{array}{l}\text { In vitro (blood } \\
\text { samples from } \\
\text { dengue patients) }\end{array}$ & $\begin{array}{l}\text { Freeze-dried papaya leaf juice for } 30 \text { minutes } \\
\text { (dose is not mentioned) }\end{array}$ & . neutralizing the dengue viral-infected plasma \\
\hline $\begin{array}{l}\text { Sathyapalan et al. } \\
(2020)\end{array}$ & Human & $\begin{array}{l}\text { Oral administration of } 1100 \mathrm{mg} \text { of papaya leaf } \\
\text { extract in tablet three times a day for } 5 \text { days }\end{array}$ & . $\quad$ significant decrease in the NS1 viraemia level \\
\hline $\begin{array}{l}\text { Senthivel et al. } \\
\text { (2013) }\end{array}$ & $\begin{array}{l}\text { Ex vivo (Bioinfor- } \\
\text { matics tool) }\end{array}$ & $\begin{array}{l}\text { Docking of quercetin onto the catalytic site } \\
\text { of the serine protease enzyme NS2B-NS3 is } \\
\text { performed using SYBYL - Surflex docking }\end{array}$ & $\begin{array}{ll}\text { Inhibition of NS2B-NS3 protease } \\
\text { Prevention of Dengue } 2 \text { Viral assembly }\end{array}$ \\
\hline
\end{tabular}

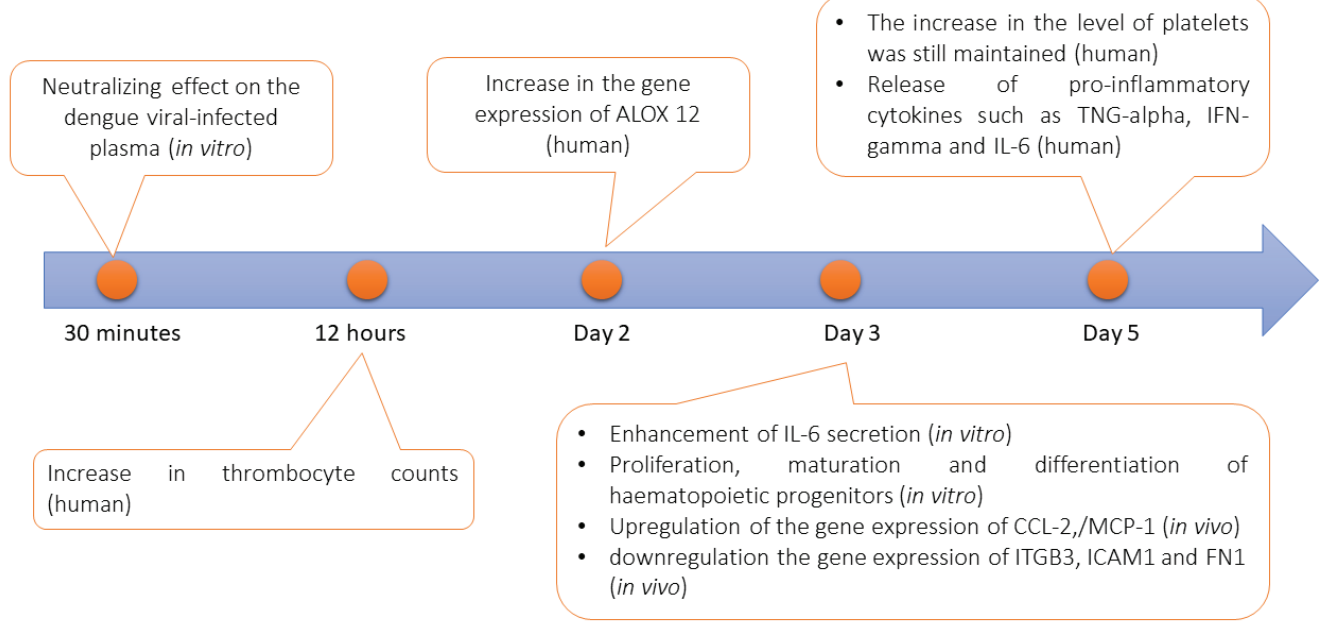

Figure 2. Timeline of the effect of papaya leaf extract.

\section{Anti-thrombocytopenic Effect of Carica papaya}

Based on the current understanding on the ability of Carica papaya extract to increase the platelet count, there is plausible explanation that it may be related to the stimulation of the thrombopoietic mechanism. In an in vivo study carried by Anjum et al. (2017), there was an increase in the platelet count observed in the Wistar rat within 72 hours after the oral administration of 150 $\mathrm{mg} / \mathrm{kg}$ of aqueous extract of papaya leaf. The study has postulated that the papaya leaf aqueous extract can stimulate and induce the megakaryopoietic/thrombopoietic stimulatory activity or cause splenic contraction to produce thrombocytes. However, the detailed downstream mechanisms were not further described and revealed in the study. On top of that, it is suggested that the increase in platelet activity might due to the presence of high flavonoids and phenolic compounds such as kaempferol, trans-ferulic acid, caffeic acid and myricetin in the papaya leaf extract ${ }^{[22]}$. Another study carried out by Sathiasivam et al. (2009) claimed that the oral administration of $15 \mathrm{mg} / \mathrm{kg}$ of powdered papaya leaves in palm oil has significantly increased the thrombocyte counts temporarily up to 12 hours in Swiss albino mice, indicating that 
papaya extract that was dissolved in oil with a lower dose $(15 \mathrm{mg} / \mathrm{kg}$ ) could also exert the anti-thrombocytopenic effect. As the effect was transient up to a short period of time, the mechanism of action has not been determined as well ${ }^{[23]}$.

Several case studies have been carried out in dengue patients to investigate the effect of papaya leaf extract. Siddique et al. (2014) proved that the oral consumption of papaya leaves juice has significantly increase the thrombocyte counts as compared to control groups within 5 consecutive days in dengue patients. Apart from increase in the thrombocyte, the study also suggested the improvement of the symptoms in dengue might due to the anti-hemolytic activity of papaya too ${ }^{[12]}$. In another study by Sathyapalan et al. (2020), the patients with severe thrombocytopenia who has taken $1100 \mathrm{mg}$ of papaya leaf extract in tablet three times a day for 5 days showed an increase in the platelet count in the first 4 days and then the platelet count is maintained on day 5 compared to the placebo group in which the platelet count increases slowly and the platelet count drops on day 5. This indicates that the Carica papaya leaf extract has the capability to maintain the platelet count where it promotes the production of platelets and could be used in severe condition, thus proving the reliability as an alternative treatment for dengue patients ${ }^{[24]}$.

This anti-thrombocytopenic effect is also supported by Subenthiran et al. (2013) in which they discovered that the gene in the red blood cells known as ALOX 12 has increased by 15 -fold among dengue patients who took Carica papaya leaf juice (50 grams) for three days. This ALOX 12 gene is known to increase the megakaryocyte production where it will lead to the conversion to platelets, thus increasing the platelet production. The platelet increase was significant at 40 hours and 48 hours, suggesting that the papaya leaf extract could rapidly induce the production of platelets in human ${ }^{[25]}$.

In a systematic review conducted by Charan et al. (2016), four different formulations of Carica papaya extract which are leaf juice, capsule form, syrup form and tablet form were given to dengue patients. Interestingly, the results showed that the platelet count has significantly increase $(p=0.005)$ in all formulations as compared to the control group. Henceforth, regardless of different formulation, this suggests that Carica papaya extract has a good bioavailability where it can accommodate high compliance in different populations that are having other health issues such as those with difficulty in swallowing or children $^{[26]}$. Another systematic review by Rajapakse (2019) critically analysed that even the dose use of papaya leaf extract are varies, no effective dose have been determine, the platelet counts of patients is increasing at day 3-5 following papaya juice, substantially shortening the hospital stay of the patients ${ }^{[2]}$.

\section{Immunomodulatory Effect of Carica papaya}

Research have been done to investigate the beneficial effect of papaya leaf extract as an immune-boosting impact to the dengue patients. A study by Sathyapalan et al. (2020) proposed that oral administration of $1100 \mathrm{mg}$ of papaya leaf extract in tablet three times a day for 5 days in human has initiated and activated the coagulation and inflammation pathways lead to the release of proinflammatory cytokines such as TNG-alpha, IFN-gamma and IL-6, that further inhibit the thrombocytopenia in patients $^{[24]}$. Similarly, another research team has proposed that the unripe papaya leaf juice extract $(10 \% \mathrm{v} / \mathrm{v})$ which consists of major compound papain, may enhance IL-6 secretion and lead to the proliferation, maturation and differentiation of multipotential heamatopoietic progenitors and then increase in thrombocyte production in mesenchymal stem cells and haematopoietic cells. Interestingly, the study also proposed that the increase in thrombocyte can be due to the action of production of thrombopoietin in the liver triggered by IL-6 ${ }^{[27]}$. An in vitro study carried out by Razak et al. (2019) proved that the 1000mg/ $\mathrm{kg}$ of oral administration of freeze-dried Carica papaya leaf juice for three days has upregulated the gene expression of CCL-2,/MCP-1 and downregulated the gene expression of ITGB3, ICAM1 and FN1 in AG129 mice with non-mouse adapted dengue virus, suggesting the papaya juice has hindered the endothelial permeability and resulted in the inhibition of cytokines expression from immune cells $^{[28]}$.

\section{Anti-viral Effect of Carica papaya}

Carica papaya extract has not only proven to increase the platelet count, but also exhibits antiviral activity. Another mechanism of action of papaya on dengue was proposed by Chinnappan et al. (2016), in which the papaya extract exerts its action on the platelet directly, by preventing the activation and aggregation of platelets and also neutralizing the dengue viral-infected plasma ${ }^{[29]}$. In a study conducted by Sathyapalan et al, (2020), they discovered that there was a significant decrease in the NS1 viraemia level $(\mathrm{p}=0.023)$ at Day 3 in the patient group that are taking $1100 \mathrm{mg}$ of papaya leaf extract. Carica papaya leaf extract may have inhibitory activity against NS2B-NS3 protease, thus preventing dengue 2 viral assembly ${ }^{[30]}$. The research team has discovered that quercetin, one of the major components in the papaya leafextract, binds to the NS2B-NS3 protease which are important in viral replication. It is proposed that quercetin has a better stability and ligand enzyme interaction as they form 6 hydrogen bonds with the amino acid at the binding site of the receptor as compared to other compounds such as caffeic acid only form 4 hydrogen bonds which is lesser than the quercetin. The research has strongly suggested that the quercetin could be developed as an effective preventive compound for dengue virus infection ${ }^{[30]}$.

\section{Conclusion and Future Perspective}

The review is intended to provide an overview of the recent outcomes of the papaya on combating dengue infection with emphasis on the targeting mechanisms of action (Figure 3).

To date, around 2168 patents have been granted for the health potential of the aerial parts of Carica papaya (www.lens.org). It is reported the total cost for a dengue fever patient was around USD 141-385 in South East $\mathrm{Asia}^{[31]}$ and accounts for $0.03 \%$ of the GDP per capita in South East Asia countries in $2010^{[32]}$. In view of the widely availability of papaya leaves, it is predicted that the ten- 
tative cost of treatment using papaya leaves will be lowered as compared with conventional treatment provided. As noted in the review, in spite of the sufficient evidences from pre-clinical in vitro, in vivo, ex vivo and small scale clinical trial in dengue patients, the papaya juice extract has not been translated into an approved clinical modality for dengue infection. It is suggested that a large scale of randomised placebo controlled trial should be conducted to further evaluate the potential of papaya leaf extract as dengue as researchers and clinicians are still in doubt of the role of papaya leaves based on few positive preliminary results, limited toxicity profile and unclear dosing regimens. In a nut shell, there is a need to have high quality clinical trials to provide scientific evidence to dispel the myth on using a papaya leaf extract in treating and prevention of dengue infection.

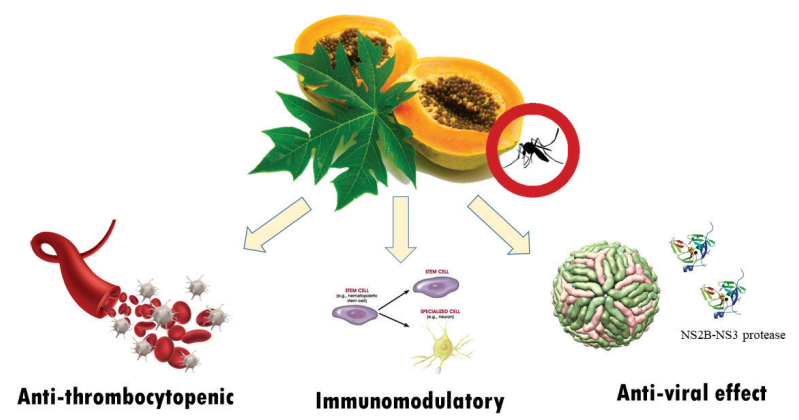

Figure 3. Possible mechanisms of Carica papaya leaf juice on dengue infection.

\section{Author Contributions}

$\mathrm{ZKB}, \mathrm{MB}, \mathrm{YXJ}$ and YRK participated in the writing of the manuscript. YSO and KKY conceptualized the project.

\section{Conflict of interest}

The authors hereby declare no competing interest.

\section{Acknowledgements}

This work was financially supported by Monash Global Asia in the 21st Century (GA21) research grant (GAHW-19-L01 \& GA-HW-19-S01).

\section{Reference}

1. Westaway EG, Brinton MA, Gaidamovich S, et al. Flaviviridae. Intervirology $1985 ; 24(4)$ : 183-92.

2. Rajapakse S, de Silva NL, Weeratunga P, et al. Carica papaya extract in dengue: A systematic review and meta-analysis. BMC Complementary Altern Med 2019; 19(1): 265.

3. Organization WH. Dengue haemorrhagic fever: Diagnosis, treatment, prevention and control. 2002: England.

4. Byard RW. Lethal dengue virus infection: A forensic overview. Am
J Forensic Med Pathol 2016; 37(2): 74-8.

5. Suppiah J, Ching S-M, Amin-Nordin S, et al. Clinical manifestations of dengue in relation to dengue serotype and genotype in Malaysia: A retrospective observational study. PLOS Neglected Trop Dis 2018; 12(9): e0006817.

6. Rajapakse S. Dengue shock. J Emerg Trauma Shock 2011; 4(1): $120-7$.

7. Lin GL, Chang HH, Lien TS, et al. Suppressive effect of dengue virus envelope protein domain III on megakaryopoiesis. Virulence 2017; 8(8): 1719-1731.

8. Hung TM, Clapham HE, Bettis AA, et al. The estimates of the health and economic burden of dengue in Vietnam. Trends Parasitol 2018; 34(10): 904-918.

9. Rajapakse S, Rodrigo C, Maduranga S, et al. Corticosteroids in the treatment of dengue shock syndrome. Infect Drug Resist 2014; 7 : $137-43$.

10. Rajapakse S. Intravenous immunoglobulins in the treatment of dengue illness. Trans R Soc Trop Med Hyg 2009; 103(9): 867-70.

11. Lee TH, Lee LK, Lye DC, et al. Current management of severe dengue infection. Expert Rev Anti-Infect Ther 2017; 15(1): 67-78.

12. Siddique O, Sundus A and Ibrahim MF. Effects of papaya leaves on thrombocyte counts in dengue--a case report. JPMA - J Pak Med Assoc 2014; 64(3): 364-6.

13. Nunes NN, Santana LA, Sampaio MU, et al. The component of Carica papaya seed toxic to A. aegypti and the identification of tegupain, the enzyme that generates it. Chemosphere 2013; 92(4): 413-20.

14. Ching S, Ramachandran V, Gew LT, et al. Complementary alternative medicine use among patients with dengue fever in the hospital setting: A cross-sectional study in Malaysia. BMC Complementary Altern Med 2016; 16: 37

15. Singh PK and Rawat P. Evolving herbal formulations in management of dengue fever. J Ayurveda Integr Med 2017; 8(3): 207-210.

16. Chapter 5: Folk Medicine. Dealing with Dengue: Diagnosing, treating, and recovering from Dengue fever, ed. G. Roberts. 2014: Thailand Retirement Press.

17. Ming R, Yu Q, Moore $\mathrm{P}$, et al. Genome of papaya, a fast growing tropical fruit tree. Tree Genet Genomes 2012; 8(3): 445-462.

18. Nugroho A, Heryani H, Choi JS, et al. Identification and quantification of flavonoids in Carica papaya leaf and peroxynitrite-scavenging activity. Asian Pac J Trop Biomed 2017; 7(3): 208-213.

19. Panche AN, Diwan AD and Chandra SR. Flavonoids: An overview. J Nutr Sci 2016; 5: e47.

20. Kooi-Yeong K, Paul Nicholas S, Marie-Odile P, et al. Compound identification and in vitro Cytotoxicity of the supercritical carbon dioxide extract of papaya freeze-dried leaf juice. Processes 2020(8): 610 .

21. Khaw KY, Parat MO, Shaw PN, et al. Factorial design-assisted supercritical carbon-dioxide extraction of cytotoxic active principles from Carica papaya leaf juice. Sci Rep 2019; 9(1): 1716.

22. Anjum V, Arora P, Ansari SH, et al. Antithrombocytopenic and immunomodulatory potential of metabolically characterized aqueous extract of Carica papaya leaves. Pharm Biol 2017; 55(1): 20432056.

23. Sathasivam K, Ramanathan S, Mansor SM, et al. Thrombocyte counts in mice after the administration of papaya leaf suspension. Wien Klin Wochenschr 2009; 121 Suppl 3: 19-22.

24. Sathyapalan DT, Padmanabhan A, Moni M, et al. Efficacy \& safety of Carica papaya leaf extract (CPLE) in severe thrombocytopenia $(<=30,000 / \mathrm{mul})$ in adult dengue - Results of a pilot study. PLoS ONE [Electronic Resource] 2020; 15(2): e0228699.

25. Subenthiran S, Choon TC, Cheong KC, et al. Carica papaya leaves juice significantly accelerates the rate of increase in Platelet count among patients with Dengue fever and Dengue Haemorrhagic Fever. Evid Based Complement Altern Med 2013; 2013: 616737.

26. Charan J, Saxena D, Goyal JP, et al. Efficacy and safety of Carica papaya leaf extract in the dengue: A systematic review and metaanalysis. Int J Appl Basic Med Res 2016; 6(4): 249-254.

27. Aziz J, Abu Kassim NL, Abu Kasim NH, et al. Carica papaya induces in vitro thrombopoietic cytokines secretion by mesenchymal stem cells and haematopoietic cells. BMC Complementary Altern Med 2015; 15: 215.

28. Mohd Abd Razak MR, Norahmad NA, Md Jelas NH, et al. Preliminary study on the expression of endothelial cell biology related genes in the liver of dengue virus infected mice treated with Carica papaya leaf juice. BMC Res Notes 2019; 12(1): 206.

29. Chinnappan S, Ramachandrappa VS, Tamilarasu K, et al. Inhibition of Platelet aggregation by the leaf extract of Carica papaya during Dengue infection: An in vitro study. Viral Immunol 2016; 29(3): 164-8.

30. Senthilvel P, Lavanya P, Kumar KM et al. Flavonoid from Carica papaya inhibits NS2B-NS3 protease and prevents Dengue 2 viral assembly. Bioinformation 2013; 9(18): 889-95.

31. Lee J-S, Mogasale V, Lim JK, et al. A multi-country study of the economic burden of dengue fever: Vietnam, Thailand, and Colombia. PLOS Negl Trop Dis 2017; 11(10): e0006037.

32. Shepard DS, Undurraga EA and Halasa YA. Economic and disease burden of dengue in Southeast Asia. PLoS Negl Trop Dis 2013; 7(2): e2055. 